\title{
Delna decentralizacija evropskega modela ustavnosodne presoje
}

\author{
UDK: 342.25:341EU
}

\author{
Novak Marko \\ Ustavno sodišče RS \\ Evropska pravna fakulteta v Novi Gorici \\ marko.novak@us-rs.si
}

\section{IZVLEČEK}

Značilnost "Kelsnovega" evropskega modela ustavnosodne presoje je med drugim centraliziranost takšne presoje $v$ enem samem organu, navadno ustavnem sodišču, ki navadno poleg abstraktne presoje - za razliko od Kelsnovega "prototipa" danes opravlja tudi presojo glede kršitve človekovih pravic. A zaradi vedno večjega kopičenja zadev pred takšnimi sodišči, ki ogrožajo njihovo normalno delovanje, se zdi nujno, da bi se centralizirani model deloma decentraliziral. To bi dosegli npr. tako, da bi tudi nižjim sodiščem še v večji meri zaupali takšno, torej ustavno presojo - toda izključno na področju kršenja ustavnih človekovih pravic in ob doslednem upoštevanju sodne prakse ustavnega sodišča.

Ključne besede: ustavno sodstvo, evropski model, decentralizacija

\section{Zgodovinsko poslanstvo sodišča s centralizirano ustavno presojo}

Značilnost evropskega modela ustavnosodne presoje, kot si ga je zamislil njegov ustanovitelj Hans Kelsen, ${ }^{\mathbf{}}$ je centralizacija takšne presoje. To pomeni, da je tovrstna presoja zaupana le enemu samemu organu, navadno ustavnemu sodišču ali drugemu organu s podobnimi pristojnostmi. Drugi organi v pravnem redu neke države pa so bodisi predmet presoje ustavnega sodišča ali pri zagotavljanju ustavne koherentnosti pravnega sistema zgolj asistirajo takšnemu centralnemu ustavnosodnemu organu, tako da napadajo domnevno neustavne

1 Glej njegovo slovito razpravo Judicial Review of Legislation, A Comparative Study of the Austrian and the American Constitution, The Journal of Politics, št. 4 (1942), str. 183-200. 
Marko Novak

\section{Delna decentralizacija evropskega}

modela ustavnosodne presoje

akte drugih državnih organov ali da mu postavljajo konkretna ustavna vprašanja.

Takšna idejna zasnova centralizirane ustavne presoje se $v$ primerjavi $s$ decentralizirano različico, ki jo pozna predvsem ameriški model ustavnosodne presoje $^{\mathbf{2}}$ in ki je uveljavljen tudi ponekod $\vee$ Evropi, $^{\mathbf{3}}$ bržkone zdi odraz določenega nezaupanja $\vee$ samo sodno vejo oblasti oz. $\vee$ redna sodišča, ki ima svoje korenine najmanj že od časa francoske revolucije. Poleg tega sta se po mnenju Ferejohna $\vee$ tridesetih letih prejšnjega stoletja $\vee$ Evropi pojavljala fašizem in nacizem, ki sta si na svojem pohodu polagoma uzurpirala sodno vejo oblasti. Pri tem gre tako prej ko slej za zgodovinsko bojazen, da bi takšno pomembno vlogo, kot je razveljavljanje aktov zakonodajalca, prepustili rednim sodnikom, katerih neodvisnost bi bila lahko $v$ danem trenutku vprašljiva. ${ }^{4}$ Peščica profesorjev prava, ki naj bi zasedli mesta $\vee$ elitni ustanovi, ki naj bi to opravljala, pa naj bi po drugi strani bolje zagotavljala neodvisnost in strokovno usposobljenost, še posebej verjetno zato, ker naj bi bili ti vsaj deloma glasniki tiste znanosti, ki je po Kelsnu kot avtonomna čista pravna znanost antipod politiki. ${ }^{\mathbf{5}}$ Po drugi strani pa so nižji sodniki $\vee$ kontinentalnem kariernem sistemu sodniškega napredovanja že po tradiciji navadno mladi, neizkušeni, vloga "negativnega zakonodajalca" s posrednimi zakonodajnimi učinki pa je gotovo strokovno veliko bolj zapleteno opravilo kot "navadna", bolj ali manj mehanična aplikacija zakonske določbe na dejanski stan. Tako so $v$ avstrijski ustavi iz leta 1920 pod Kelsnovim vplivom, ki je zasnoval poglavje o ustavnem sodstvu, celo izrecno prepovedali rednim sodiščem, da bi izvajala ustavnosodno presojo. 6

Poleg tega je tradicionalni razlog, ki opravičuje evropski model ustavne presoje, pomen načela pravne varnosti v sistemih kontinentalnega prava, ki ne poznajo doktrine stare decisis oz. doktrine o obvezni (tj. formalni) veljavi precedenčnega prava. Če bi redna sodišča - v takšnih pogojih - lahko opravljala ustavno presojo zakonodaje, bi to po Kelsnu lahko ogrozilo načelo pravne varnosti, saj bi lahko pripeljalo do tega, da bi različna sodišča izrekala različne sodbe glede ustavne veljavnosti določene zakonodaje. Zato naj bi torej potrebovali centraliziran sistem ustavne presoje. Kelsen je pri tem opozarjal na razliko z ameriškim pravnim sistemom, kjer velja doktrina stare decisis, ki naj bi s hierarhičnim sistemom precedensov kot formalnopravnih virov preprečevala neenotnost

2 Glej infra.

3 Tako na Danskem, Norveškem, Švedskem, Irskem in v Estoniji. Glej A. Mavčič, The Constitutional Review, BookWorld Publications, The Netherlands (2001), str. 24.

4 Glej J. E. Ferejohn, Judicializing Politics, Politicizing Law, Law and Contemporary Problems, let. 65, št. 3 (2002), str. 56-57.

5 Glej H. Kelsen, Reine Rechtslehre, Verlag Deuticke, Wien (1934). 


\section{Marko Novak \\ Delna decentralizacija evropskega modela ustavnosodne presoje}

stališč sodišč (glede ustavnih vprašanj). Toda ta doktrina tudi v ZDA po njegovem ne velja absolutno, kar naj bi pomenilo, da gre pravzaprav za nepopolno pravno varstvo. ${ }^{7}$

Sicer pa se tudi zdi, da je vse od francoske buržoazne revolucije evropsko (pravno) okolje bilo še donedavna močno zavezano načelu ljudske suverenosti in je bilo zato nekako zadržano do ustavnosodne presoje, ki $\vee$ ožjem pogledu deluje pravzaprav nedemokratično, tako da je kvečjemu preneslo le en specializiran organ, ki bi izvajal takšno presojo, ne pa obsežen aparat rednega sodstva, ki bi izvajal decentralizirano ustavno presojo.

Izkušnje z izrazitim totalitarnim sistemom so imele tudi bivše komunistične države $\vee$ Vzhodni Evropi in glede na logiko prej zapisanega verjetno ni čudno, da so se vse po vrsti - torej v luči zagotavljanja politične stabilnosti odločile za evropski model ustavnosodne presoje. ${ }^{\mathbf{3}}$ Zanimivo je, da so se predvsem skandinavske države, za katere se zdi, da niso poznale tako izrazitih totalitarnih sistemov, odločile za ameriški model ustavnosodne presoje.

Zgodovinsko poslanstvo ustavnih sodišč s centralizirano ustavno presojo je bilo tako med drugim tudi kot reakcija na totalitarne režime oz. na zlorabe prava zakonodajalca, izvršilne in sodne veje oblasti, ki so $v$ takšnih režimih delovali kot enotna veja oblasti. Pri tem se zdi, da bolj kot je bila zgodovinska izkušnja s takšnimi režimi brutalna, večjo vlogo so po "revoluciji" ti organi dobili predvsem v imenu varstva človekovih pravic (ustavna pritožba) ter zagotavljanju politične stabilnosti ("abstraktna presoja" ustavnosti). Tako se morda ne zdi presenetljivo, da je eno izmed najbolj izrazitih ustavnih sodišč v kontinentalnem pravnem sistemu prav nemško Zvezno ustavno sodišče.

Najmočnejša alternativa evropskemu modelu ustavnega sodišča je seveda veliko starejši ameriški model, kjer je sodna presoja ustavnosti (popolnoma) decentralizirana. Če je tipična značilnost evropskega modela ustavne presoje po Kelsnu - t. i. abstraktna presoja ustavnosti zakonov, je tipična značilnost ameriškega modela odločanje o kršitvi ustavnih pravic $v$ konkretnih postopkih. ${ }^{9}$ $\checkmark$ takšnem sistemu vsa sodišča poleg drugih pristojnosti izvajajo tudi ustavnosodno presojo, najvišje, navadno vrhovno sodišče kot zadnja instanca pa "skrbi" za koordinacijo in enotnost takšne sodne prakse. Resda gre tu $v$ neposrednem smislu za inter partes učinke $v$ konkretnem sporu, a zaradi splošnega formalnega

6 H. Kelsen, Judicial Review of Legislation, op. cit., str. 185-186.

7 Ibidem.

8 J. E. Ferejohn, Constitutional Review in the Global Context, Legislation and Public Policy, št. 6 (2002), str. 49.

9 L. López Guerra, The Functions of Constitutional Courts, http://www.aals.org/profdev/constitutional/lopezguerra.html. 


\section{Marko Novak \\ Delna decentralizacija evropskega \\ modela ustavnosodne presoje}

precedenčnega učinka takšnih odločitev gre $v$ določenih primerih pravzaprav za posredne erga omnes učinke. To pa je seveda odvisno od formalne veljavnosti določenega precedensa $v$ posamezni sodni pristojnosti oz. na ustreznem sodnem nivoju (torej ali je precedens binding, torej obvezen ali le persuasive, prepričljiv).

Po besedah Ferejohna pomeni takšna pristojnost rednih sodišč, da lahko vsak sodnik, npr. celo sodnik v "nekem" Poughkeepsiju ugotovi neustavnost določenega predpisa. To pa naj bi bilo prav tisto, česar Evropejci nočemo. ${ }^{\mathbf{1 0}}$ Toda pri tem je treba vedeti, da ameriški redni sodniki to postanejo šele ob koncu svoje kariere bodisi odvetnika, tožilca itd. Gre torej za starejše in veliko bolj izkušene sodnike kot $v$ kontinentalnem pravnem sistemu, tako da se vsaj po izkušnjah naši sodniki - razen seveda na višjih instancah - težko primerjajo z njimi. To pa bi bil lahko razlog, da bi lahko (le) takšnim, izkušenim sodnikom zaupali tako pomembno pristojnost, kot je ustavnosodna presoja.

Poleg evropskega in ameriškega obstaja seveda tudi t. i. mešani model ustavnosodne presoje, kjer poleg centralnega organa ustavnosodne presoje takšno presojo opravljajo tudi redna sodišča. Gre za nekakšno vmesno različico med decentraliziranim in centraliziranim sistemom ustavnosodne presoje. Takšen model vključuje tako elemente decentraliziranega kot centraliziranega sistema. Poleg centralnega organa, navadno ustavnega sodišča ali (oddelka) vrhovnega sodišča, tudi druga sodišča izvajajo $v$ neki meri ustavno presojo zakonov. ${ }^{11}$

Pomembno dejstvo, ki ga ne smemo spregledati, je tudi to, da ustavna sodišča s centraliziranim tipom ustavne presoje $v$ začetku gotovo niso poznala tolikšnega števila sporov kot danes. Prav zanimiv bi bil podatek o tem, koliko primerov je imelo avstrijsko ustavno sodišče $\vee$ prvih letih svojega delovanja (npr. vsaj $\vee$ zadevah "abstraktne presoje", če je že znano to, da to sodišče ni poznalo varstva človekovih pravic).

Tako se glede na spremenjene okoliščine danes po mnenju nekaterih zdi, da je takšen evropski sistem ustavnega sodstva vsaj deloma v krizi. ${ }^{\mathbf{1 2}}$

10 Glej J. Ferejohn, Constitutional Review in the Global Context, op. cit., str. 57.

11 Takšen sistem poznajo denimo na Portugalskem, v Grčiji, Švici. Glej A. Mavčič, op. cit., str. 26.

12 Tako npr. L. López Guerra, op. cit., ibidem, predvsem pa V. F. Cornella, The European model of constitutional review of legislation: Towards decentralization? Int'I J. of Constitutional law (2004), str. 461. Naj tu omenim, da je prof. V. F. Cornella ugleden mednarodni ustavni pravnik, sicer eden izmed urednikov vodilne mednarodne revije za primerjalno ustavno pravo International Journal of Constitutional Law (I-CON). 


\section{Kriza evropskega modela ustavnosodne presoje}

Razlogi za sodobno krizo evropskega centraliziranega modela ustavnosodne presoje se zdijo tako načelne kot pragmatične narave. ${ }^{\mathbf{1 3}}$ Razlogi načelne narave so $v$ samem sistemu centralizirane presoje glede na njegov pomen $v$ širšem političnem kontekstu pravnega sistema, sistema delitve oblasti, delovanja pravne in demokratične države, primerjalne ureditve, pravne kulture itd. Poglavitni razlog pragmatične narave pa bodisi izhaja iz vsebine takšne vrste ustavne presoje, je njen spremljevalni pojav, ali pa izvira iz nekih drugih, bolj zunanjih okoliščin.

Četudi bi načelni razlogi, ki zadevajo vsebino oz. jedro sistema, morali biti poglavitni za razpravljanje o krizi takšnega sistema, je morda bolj pošteno, če priznamo, da je pravzaprav pragmatični razlog povzročil, da smo sploh pričeli resno razpravljati tudi o načelnih razlogih. $V$ nadaljevanju zato najprej govorimo o pragmatičnem razlogu za krizo centraliziranega sistema ustavnosodne presoje.

\subsection{Pragmatični razlog za krizo}

Glavni razlog za krizo centraliziranega sistema in tudi krizo kontinentalnega sodstva nasploh so za gotovo preobremenjenost sodišč in posledični sodni zaostanki. Tu seveda ne razpravljamo o splošnih vzrokih za takšne zaostanke, ${ }^{\mathbf{1 4}}$ je pa pričujočo razpravo, upam da mogoče razumeti tudi kot poskus njihovega zmanjševanja $\vee$ prihodnosti, vsaj kar se tiče ustavnosodne presoje. Znano je, da poleg rednih sodišč takšen strmo naraščajoč pripad zadev tare domala celotno kontinentalno ustavno sodstvo. Statistični podatki o pripadu slovenskega ustavnega sodišča so široko dostopni v raznih poročilih Ustavnega sodišča RS oz. v publikacijah in razpravah o Ustavnem sodišču. ${ }^{\mathbf{1 5}}$

Takšni problemi tako pestijo npr. tudi nemško in špansko ustavno sodišče, ki obe poznata ustavno pritožbo. Tudi v Italiji, ki ne pozna ustavne pritožbe, ni situacija nič kaj rožnata. Vsi ti sistemi zato mrzlično iščejo filtre za omejitev

13 Nekoliko drugače denimo Cornella, ki govori o notranjih in zunanjih razlogih za krizo centraliziranega sistema ustavne presoje. Glej V. P. Cornella, supra, ibidem.

14 O splošnejših, lahko bi rekli tudi globljih vzrokih za preobremenjenost sodišč glej na primer S. L. Roach Anelu, Law and Social Change, SAGE Publications, London (2000), str. 108-123.

15 Glej npr. J. Čebulj, Poročilo o delu za leto 2006, http://www.us-rs.si (pod rubriko O sodišču). 
Marko Novak

Delna decentralizacija evropskega

modela ustavnosodne presoje

pripada na ustavna sodišča, ${ }^{\mathbf{1 6}}$ ki bolj ali manj koketirajo s ameriškim diskrecijskim načinom selekcioniranja zadev, ki jih sprejema $v$ odločanje Vrhovno sodišče ZDA. Skupni imenovalec takšnih filtrov pa je slej ko prej omejitev sprejema zadev med najpomembnejše ustavnopravne zadeve.

\subsection{Načelni razlogi za (večjo) decentralizacijo}

Načelni razlogi, ki izhajajo iz krize evropskega (tj. centraliziranega) modela ustavne presoje kot deloma zastarelega, govorijo $v$ prid njegove večje decentralizacije. $\vee$ nadaljevanju tako predstavljamo tri skupine takšnih načelnih razlogov.

Najprej je tu razlog krepitve oz. homogenizacije sodne veje oblasti, ki bi ga takšna delna decentralizacija ustavnosodne presoje lahko prinesla. $V$ sistemu delitve oblasti bi tako sodna veja kot celota na čelu z Ustavnim sodiščem - v ustavnopravnih zadevah - tako bolj enotno delovala zoper drugi dve veji oblasti in bi tako glede ustavne določbe 125. člena Ustave, da so sodniki vezani "na Ustavo in zakon", pomenila tudi to, da bi prvi del te besedne zveze še bolj zaživel v praksi. Ker so pomemben del ustave človekove pravice, bi to pomenilo še večjo integriranost njihovega pomena $\vee$ družbi. $\vee$ sistemu parlamentarne demokracije so bila sodišča zavezana predvsem zakonu kot temeljnemu izrazu suverenosti ljudstva. Obdobje ustavne demokracije pa temelji prvenstveno na ustavi kot temeljnem družbenem aktu in prav se zdi, da tudi redno sodstvo to še bolj neposredno upošteva oz. uresniči. $Z$ bolj decentraliziranim sistemom ustavne presoje, ki bi tega še bolj približal rednim sodiščem, bi s tem še povečali zavest rednih sodnikov glede pomena oz. vsebine ustave.

Drugi načelni razlog za večjo decentralizacijo takšne presoje pa je povezan $s$ tipično vlogo, ki naj jo ustavno sodišče odigra v sistemu delitve oblasti. Zakaj je sploh pomembno, da imamo ustavno sodišče in kaj naj ne bi bila njegova vloga oz. bi morala biti vloga nižjih sodiščc Sodobne razmere so zaradi astronomskega naraščanja števila zadev namreč nekatera ustavna sodišča pripeljale $\checkmark$ absurdne položaje. Vse več zadev namreč pomeni tudi večje število t. i. lahkih zadev, kjer gre lahko tudi za bolj ali manj preprosta procesno-pravna vprašanja, s katerimi se npr. pogosto ukvarjajo sodniki na najnižjih stopnjah ali nižji uradniki $v$ določenih upravnih organih. To pomeni jemanje dragocenega časa ustavnim sodnikom, ki naj bi se kot vrhunski strokovnjaki vendarle

16 Glej L. Lopez Guerra, The Functions of Constitutional Courts, op. cit., ibidem. 


\section{Marko Novak \\ Delna decentralizacija evropskega modela ustavnosodne presoje}

ukvarjali predvsem $\mathrm{s}$ t. i. težkimi primeri. ${ }^{17} \mathrm{~V}$ teh primerih gre pogosto za povsem zapletena vprašanja pravno-politične narave, ${ }^{\mathbf{1 8}}$ kjer je ustavno sodišče $v$ položaju, da deluje kot nekakšen "posredni zakonodajalec" z daljnosežnimi (erga omnes) učinki svojih odločb. Preprosto rečeno se zdi "škoda" najbolj vrhunskih pravnikov za ukvarjanje z najbolj enostavnimi procesno-tehničnimi vprašanji. No, neki bolj diskrecijski predhodni sistem za sprejemanje zadev v obravnavo bi to nedvomno bistveno popravil, seveda pa morajo biti, kot bomo videli $v$ nadaljevanju, za to izpolnjeni določeni pogoji. Zaradi izjemno širokih posledic odločb ustavnega sodišča se zdi še posebej pomembno, da imajo ustavni sodniki za kakovostne odločitve dovolj časa. Funkcije ustavnega sodnika namreč ni moč primerjati s funkcijo sodnika rednega (nižjega) sodišča, kjer je zaradi narave samega dela odločanje pogosto bolj rutinsko.

Tretji načelni razlog za delno decentralizacijo pa se nanaša na smiselnost tradicionalnega koncepta centralizirane ustavne presoje, tipične za evropski model ustavne presoje, $v$ novih pogojih delovanja evropskega prava $\vee$ nacionalnih sistemih. Gre za nekatere pristojnosti, ki jih imajo po evropskem pravu (za nas po novem) redni sodniki, zaradi česar bi bila "ekskluzivnost" ustavne presoje $\vee$ določenih vidikih lahko morda tudi vprašljiva. $\vee$ terminologiji evropskega prava pravijo temu neposredni učinek evropskega prava ( $v$ nacionalnih pravnih sistemih), gre pa za to, da ima neposredno učinkujoča določba prava EU pod določenimi pogoji (če gre za jasno brezpogojno določbo in če njena uporaba ni odvisna od nadaljnjih dejanj s strani evropskih ali nacionalnih organov) ${ }^{19}$ vedno primat glede na podobno določbo nacionalnega prava. Tako mora nacionalno sodišče takrat, ko gre za konflikt z domačo določbo, neposredno uporabiti takšno evropsko določbo. $V$ tem primeru sodnik ne sme čakati na spremembo nacionalnega prava, bodisi da takšno spremembo opravi ustavno sodišče ali zakonodajalec. ${ }^{\mathbf{2 0}}$ Sicer pa ima država dolžnost, da takšno konfliktno nacionalno določbo odpravi oz. uskladi, četudi je neuporabljiva. ${ }^{\mathbf{2 1}} \mathrm{V}$ tem kontekstu opravljajo nacionalni redni sodniki pravzaprav neke vrste presojo ustavne narave glede skladnosti domače zakonodaje z evropsko, kar pomeni, da tudi v centraliziranem sistemu ustavne presoje takšna - sicer iz konkretnega spora

17 Gre za primere, kjer ni jasne ustavne opore oz. ni neke prejšnje odločbe o podobnem vprašanju. Vedno bolj tudi $v$ kontinentalnem pravu $v$ takšnem primeru pravimo, da ni precedensa oz. prejšnjega vzorčnega primera.

18 Tudi sam Kelsen je bil pripravljen to priznati, četudi ga danes citiramo bolj v smislu zagovarjanja funkcije ustavnega sodišča kot zgolj negativnega zakonodajalca. - Glej H. Kelsen, Judicial Review of Legislation, op. cit., str. 200.

19 Glej zadevo Van Duyn, št. 41/74, 1974, ECR 1337.

20 Glej zadevo Simmenthal, št. 106/77, 1978, ECR 629, str. 651-52.

21 Glej zadevo French Marchant Seamen, št. 167/73, 1974, ECR 359. 
Marko Novak

Delna decentralizacija evropskega

modela ustavnosodne presoje

izvirajoča - abstraktna presoja skladnosti nacionalne zakonodaje ni več ekskluzivno zaupana le ustavnemu sodišču. Resda tu ne gre za presojanje ustavnosti nacionalne zakonodaje $v$ dobesednem smislu, temveč njene "evropskosti", a položaj se zdi več kot podoben, in to še toliko bolj zaradi primata evropskega (tudi sekundarnega) prava nad nacionalnim ustavnim pravom (v t. i. "evropskih" zadevah). Po mnenju Cornelle ${ }^{22}$ se to zdi dober argument, da bi evropski model ustavne presoje vsaj deloma decentralizirali, saj redni sodniki te vrste presojo $\mathrm{v}$ nekem smislu že zdaj (lahko) opravljajo.

\section{Organizacija ustavnosodne presoje v decentraliziranem modelu}

\subsection{Diskrecijski sistem ustavnosodne presoje}

Iz primerjalnega ustavnega prava je znano, da diskrecijski način odločanja o tem, katere pritožbe bo sprejelo $v$ odločanje, pozna predvsem Vrhovno sodišče ZDA, ki sicer deluje $\vee$ splošnem anglosaškem (common law) precedenčnem sistemu (z veljavo doktrine stare decisis). Vendar ameriško vrhovno sodišče te diskrecijske prisojnosti ni imelo že od samega začetka svojega delovanja. Da bi to sodišče bilo zmožno obvladati pripad zadev, so z zakonom iz leta 1925 dodatno uvedli tudi diskrecijsko, tj. prosto presojo sodišča, da izbere tiste primere, ki se mu zdijo dovolj pomembni za obravnavo. ${ }^{\mathbf{2 3}}$ Tako sta sočasno obstajali obvezna in diskrecijska pristojnost tega sodišča, pri čemer je pričela prevladovati slednja. Ker so $\vee$ ZDA razen $\vee$ nekaterih primerih leta 1988 ukinili redno pritožbeno pot na Vrhovno sodišče, danes to sodišče obravnava zadeve skoraj izključno prek diskrecijskega instituta certiorari, kar pomeni pretežno

22 V. F. Cornella, op. cit., str. 16-19. Po njegovem mnenju gre za takšen zunanji pritisk na to, da se evropski model decentralizira, tudi v kontekstu Sveta Evrope in Evropskega sodišča za človekove pravice, kajti večina nacionalnih sistemov članic Sveta Evrope pozna ustavno določbo, po kateri so ratificirane mednarodne pogodbe nad domačo zakonodajo in se uporabljajo neposredno, kar pomeni, da bi v primeru nasprotja med nacionalno zakonodajo in mednarodno pogodbo redni sodniki morali uporabiti mednarodno pogodbo. Tudi to po njegovem mnenju $v$ nekem smislu razvrednoti "ekskluzivnost 'ustavne'" presoje $s$ strani ustavnega sodišča.

23 K. Zweigert, H. Kötz, Introduction to Comparative Law, Clarendon Press, Oxford (1998), str. 254. 


\section{Marko Novak \\ Delna decentralizacija evropskega modela ustavnosodne presoje}

odločanje o sprejemu zadev v odločanje po prostem preudarku. ${ }^{\mathbf{2 4}}$ Resda tudi to sodišče letno prejme več tisoč zadev, a odloča le o kakšnih sto, pri čemer je predhodni postopek njihove izbire, kjer praviloma sploh ni obrazložitve za zavrnitev odločanja o zadevi, veliko hitrejši in manj potraten kot naš predhodni postopek odločanja o zadevah.

Zaradi neobvladljivega pripada zadev na slovensko ustavno sodišče, ki se z leti le še povečuje, ${ }^{\mathbf{2 5}}$ je predlog za uvedbo podobnega diskrecijskega sistema, pri katerem bi naše ustavno sodišče po vzoru ameriškega vrhovnega sodišča odločalo le o kakšnih sto primerih letno, že pred nekaj leti podal bivši ustavni sodnik Krivic. ${ }^{\mathbf{2 6}}$ Danes so takšni predlogi oz. vsaj razmišljanja o tem v slovenski strokovni javnosti ponovno aktualna, tudi zato, ker se razmere niso nič kaj izboljšale. ${ }^{\mathbf{2 7}}$ Gre namreč za problem iskanja izhoda iz krize tudi samega evropskega (centraliziranega) modela ustavnega sodišča, ki je v slovenski različici izredno širokih pristojnosti ustavnega sodišča še toliko bolj zapleten.

Če o tem še malce naprej razmišljamo, lahko zapišemo, da je takšen diskrecijski sistem, ki bi izboljšal stanje na ustavnem sodišču glede pripada zadev in bi s tem gotovo prispeval $k$ (še) bolj kakovostnemu odločanju te ustanove, $v$ našem pravnem sistemu smiseln in upravičen le, če bi koncept ustavnosodne presoje vsaj delno ${ }^{\mathbf{2 8}}$ decentralizirali. Zato pa bi morali izpolniti najmanj dva pogoja, če že ne še kaj več.

Prvi se nanaša na to, da bi uvedli t. i. subsidiarni sistem ${ }^{\mathbf{2 9}}$ ustavne presoje, kjer bi bilo Ustavno sodišče le vrh piramide v takšnem sistemu, kar pomeni, da bi moralo biti varstvo ustavnosti zagotovljeno že na temeljni sodni ravni pred

24 G.R. Stone et al., Constitutional Law, Little Brown and Company, Boston (1991), str. 125-126. O institutu certiorari glej več npr. v M. Novak, Certiorari, Pravna praksa št. 23 (2005), str. 21.

25 Po stanju na dan 31. 12. 2006 je imelo Ustavno sodišče RS v delu 2981 zadev ali kar $87 \%$ več kot na isti dan $v$ prejšnjem letu. $V$ prvem mesecu in pol tega leta pa je prejelo kar 532 zadev, kar pomeni, da bo ob nadaljevanju tega trenda pripad ob koncu tega leta okrog 5000 novih zadev (oz. 7000 vseh nerešenih zadev). Glej J. Čebulj, Poročilo o delu za leto 2006, op. cit., str. 5, 7.

26 Pri tem je omenjal sicer kasneje opuščeni projekt na nemškem Zveznem ustavnem sodišču. O podobnem projektu pa razmišljajo tudi v Španiji. - Glej L. López Guerra, op. cit., ibidem.

27 Glej npr. mnenje predsednika Ustavnega sodišča dr. Čebulja, Delo z dne 8. 11. 2005, str. 2.

28 Takšna delna decentralizacija bi lahko morda že pomenila, da smo se čistemu centraliziranemu sistemu ustavne presoje odpovedali in sprejeli neke vrste mešani, delno decentralizirani model. Šlo bi npr. za širši obseg decentralizacije ustavnosodnega odločanja, kot smo jo do zdaj poznali (npr. pristojnosti upravnega sodišča po 4. členu Zakona o upravnem sporu in $n p r$. $v$ določenem vidiku tudi glede novega Zakona o varstvu pravice do sojenja brez nepotrebnega odlašanja).

${ }^{29} \mathrm{Na}$ načelo subsidiarnosti se vse bolj sklicujeta tudi obe veliki evropski sodišči, ki sta vedno bolj zasuti s primeri iz držav članic bodisi EU ali Sveta Evrope. Pri tem se sklicujeta na primarnost sodnega varstva pred nacionalnimi sodišči. 


\section{Marko Novak \\ Delna decentralizacija evropskega \\ modela ustavnosodne presoje}

rednimi sodišči. Bilo pa bi izrazito $v$ nasprotju $z$ načelom (ustavne) pravne varnosti, če bi Ustavno sodišče - sicer po nekem predhodnem postopku izbire zadev - izbralo le kakšnih sto zadev letno, ${ }^{\mathbf{3 0}}$ pri tem pa varstvo ustavnih določb ne bi bilo zagotovljeno na nižjih stopnjah. Zato bi v takšnih pogojih morala redna sodišča nekoliko bolj temeljito kot do zdaj upoštevati oz. uporabljati sodno prakso Ustavnega sodišča, ${ }^{31}$ Ustavno sodišče pa bi z letnim izborom (izmed vseh zadev, ki bi jih prejelo) le usmerjalo takšno ustavnopravno prakso glede na razvoj oz. najnovejša družbena dogajanja $v$ slovenskem pravnem prostoru. Ustavno sodišče bi tako še naprej opravljalo - v Kelsnovem modelu odločilno vlogo zagotavljanja enotnosti ustavne razlage.

Drugi pogoj za takšen sistem, v katerem bi redna sodišča morala dosledno uporabljati sodno prakso Ustavnega sodišča $\vee$ konkretnih postopkih in tako ustrezno zagotavljati varstvo ustavnosti oz. varstvo človekovih pravic, ${ }^{\mathbf{3 2}}$ pa moral biti $\vee$ tem, da bi odločbe ustavnega sodišča končno postale formalni pravni vir oz. bi dobile tudi t. i. precedenčne (tj. erga omnes) učinke $v$ formalnem smislu. To seveda ne pomeni, da bi bila takšna odločitev obvezna za neko redno sodišče le $v$ konkretnem primeru, iz katerega izhaja (t. i. inter partes učinki). ${ }^{\mathbf{3 3}}$ Formalna veljavnost precedensa (v common law sistemih) po doktrini stare decisis namreč pomeni, da ga sodišče mora uporabiti (tako kot npr. zakon), če gre za precedens višjega sodišča v okviru iste sodne pristojnosti, pri čemer so precedensi Vrhovnega sodišča ZDA obvezni za vsa sodišča $\vee$ državi (ko gre - v kontekstu ZDA - za vprašanja zveznega prava).

Precedensi Ustavnega sodišča bi tako (tudi formalno) veljali za vsa sodišča v državi - seveda le glede razlage ustavnih določb. Pri tem bi sodišča v konkretnih primerih vendarle imela dovolj manevrskega prostora, da določeno prejšnjo odločitev Ustavnega sodišča ne upoštevajo, če bi šlo za drugačen primer (drugačna dejstva primera), kar je sicer stalna praksa nižjih sodišč v sistemu common law, ko gre za (ne)upoštevanje lastnih precedensov oz. precedensov višjih sodišč. Če pa bi šlo za bistveno enaka dejstva primera, potem bi nižje sodišče

30 Že zdaj Ustavno sodišče izda kakšnih 200 (vsebinskih oz. plenarnih) odločb letno, ostalo pa so $v$ glavnem sklepi bolj procesne narave, ki pa sodnikom in svetovalcem kljub temu vzamejo izredno veliko časa.

$31 \mathrm{O}$ tem sicer nekaj več tudi v nadaljevanju.

32 "Ni naloga Ustavnega sodišča, da vedno znova $v$ številnih posameznih primerih pove, kako morajo pristojni organi in sodišča postopati $v$ skladu $s$ človekovimi pravicami in temeljnimi svoboščinami. Naloga ustavnega sodišča je, da vzpostavi standarde varstva človekovih pravic, ki bodo zatem spoštovani $v$ vseh posameznih postopkih pred pristojnimi sodišči." J. Čebulj, Poročilo o delu za leto 2006, op. cit., str. 21.

33 Kot to zdaj velja v smislu 112. člena Zakona o sodiščih ali v primeru konkretne ustavne presoje iz 156. člena Ustave, kjer gre za neke vrste predhodno odločanje Ustavnega sodišča glede ustavnosti določene zakonske materije. 


\section{Marko Novak \\ Delna decentralizacija evropskega modela ustavnosodne presoje}

seveda moralo odločiti enako, kot je bilo prej odločeno - ne $v$ smislu ustaljene sodne prakse, temveč $v$ smislu doktrine stare decisis, kjer že ena sama precedenčna odločitev zavezuje.

Zdi se, da vsaj za enkrat takšen sistem pri nas ne bi bil primeren za odločanje o vseh vprašanjih iz pristojnosti ustavnega sodišča. Za razliko od nekaterih zgoraj navedenih avtorjev, ki bi šli $v$ bolj korenito decentralizacijo ustavnega sodstva, ${ }^{\mathbf{3 4}}$ razpravljamo spodaj o tem, da bi bil takšen sistem ustrezen predvsem za odločanje o ustavnih pritožbah zaradi kršitve človekovih pravic ali temeljnih svoboščin, ${ }^{\mathbf{3 5}}$ kar pa je zdaj daleč največji pripad zadev na Ustavno sodišče. $V$ tem smislu torej govorimo o delni decentralizaciji. Za ustavnosodno presojo zakonov pa takšen sistem - vsaj zaenkrat - morda ne bi bil primeren, saj je $v$ tem primeru potrebna zelo kompleksna, zapletena študijska analiza, za kar se zdi, da so bolj usposobljeni vrhunski pravni strokovnjaki v kolegijskem telesu ob znatni podpori svetovalcev. Ne pozabimo ob tem že omenjenega dejstva, da sodniki $v$ decentraliziranem sistemu ustavne presoje, ki sicer izvajajo takšno presojo, navadno pričnejo opravljati svojo funkcijo šele po predhodni karieri $\vee$ drugih pravniških poklicih.

Menimo, da bi s takšnim delno decentraliziranim sistemom ustavne presoje dosegli kar nekaj pomembnih ciljev: (a) oblikovali bi bolj enoten in pregleden sistem ustavnosodne prakse; (b) razbremenili bi Ustavno sodišče, zato da bi se lahko (še) bolj kakovostno ukvarjalo s posameznimi problemi; (c) ustavna določba 125. člena, da so sodniki vezani na ustavo in zakon, bi še bolj zaživela $\checkmark$ svojem prvem delu; (č) v polnem, namreč tudi formalnem obsegu bi zaživela tudi določba tretjega odstavka 1. člena Zakona o Ustavnem sodišču, ki pravi, da so odločbe Ustavnega sodišča obvezne (tj. odločitev ustavnega sodišča kot formalni pravni vir).

Seveda se ob tem nujno porajajo tudi pomisleki. Najprej ta, ki takšen delno decentralizirani sistem postavlja pod vprašaj spričo dejstva, da so (tudi redna) sodišča že zdaj pretirano obremenjena, še neka dodatna pristojnost pa bi jim povzročala še dodatne probleme. No, tu je pomislek upravičen, saj bi prej morali zagotoviti razbremenitev rednih sodišč. Vendar bi redna sodišča o ustavnih vprašanjih razpravljala večinoma le postransko oz. mimogrede (incidentally), ob razpravljanju o drugih, npr. "zakonskih" vprašanjih pri denimo neki pritožbi na višje sodišče ali pri upravnem sporu zoper neki upravni akt.

$34 \mathrm{Ti}$ bi namreč decentralizirali evropski model tudi v smislu decentralizirane abstraktne ustavne presoje.

35 Tam tudi nekaj več o konkretnem "sodelovanju" med rednimi sodišči in Ustavnim sodiščem na tem področju. 


\section{Marko Novak \\ Delna decentralizacija evropskega \\ modela ustavnosodne presoje}

\subsection{Decentralizacija odločanja o ustavnih pritožbah}

Delna decentralizacija ustavne presoje in s tem delna razbremenitev ustavnega sodišča bi bila seveda najbolj zaželena tam, kjer gre sicer za največji pripad: tj. na področju odločanja o kršitvah človekovih pravic, ki jih stranke uveljavljajo pred ustavnim sodiščem z ustavno pritožbo. Vendar bi tudi tukaj, kot že zgoraj nakazano, za uspešno (vsebinsko legitimno in učinkovito), četudi delno decentralizacijo, moralo biti izpolnjenih kar nekaj predpostavk:

Prva izmed teh predpostavk je gotovo obveznost odločb ustavnega sodišča $\vee$ smislu (pravega) precedenčnega prava (tj. $\vee$ določenem smislu erga omnes učinkov). Že zdaj torej tretji odstavek 1. člena Zakona o Ustavnem sodišču (ZUstS) govori o tem, da so odločbe Ustavnega sodišča obvezne, a tu gre, ko govorimo o t. i. Up-zadevah, zaenkrat le za t. i. inter partes učinke. Da gre za takšne učinke odločb, se zdi, da ne izhaja neposredno iz same Ustave, temveč bolj iz pravne tradicije našega pravnega sistema, kjer imajo neposredne erga omnes učinke le splošni pravni akti (in tudi odločbe Ustavnega sodišča v t. i. abstraktnih zadevah). Posredno pa je takšne učinke, ki veljajo le med strankami nekega spora, razbrati iz zakonodaje, med drugim tudi npr. iz drugega odstavka 11. člena Zakona o sodiščih. ${ }^{\mathbf{3 6}}$

Kot že omenjeno, je t. i. sistem stare decisis $v$ bistvu doktrina, kar pomeni, da ni predmet urejanja $\vee$ pravnih aktih, temveč je predvsem stvar prakse sodišč na temelju pravne tradicije in kolektivne pravne zavesti. Zato bi morebitna sprememba naše Ustave, ki bi hotela uvesti (pravi) precedenčni sistem (morebiti le na nivoju odločb Ustavnega sodišča), bolj učinkovala pri doseganjz nekega splošnejšega konsenza, kot pa da bi bila nujno potrebna $v$ formalnem smislu. Tako kot bi bilo moč razlagati tretji odstavek 1. člena Zakona o Ustavnem sodišču glede obveznosti odločb Ustavnega sodišča ${ }^{\mathbf{3 7}}$ načina na dva načina (inter partes ${ }^{\mathbf{3 8}}$ ali erga omnes učinki $\vee$ zadevah ustavnih

36 Ta se glasi: "Sodnik je pri uporabi prava neodvisen tudi v razmerju do sodišča višje stopnje, ki je v konkretni zadevi že izrazilo svoje pravno mnenje."

37 "Odločbe Ustavnega sodišča so obvezne."

38 Temu stališču bi bilo blizu naslednje mnenje: "Učinki odločb Ustavnega sodišča so $v$ postopku odločanja o ustavni pritožbi gotovo drugačni kot v postopku abstraktne presoje. Odločbe, s katerimi Ustavno sodišče odloča o ustavnih pritožbah, so po svoji naravi precej blizu odločbam, izdanim v sodnih postopkih." Glej D. Wedam Lukić, pritrdilno ločeno mnenje v zadevi št. Up-331/98. Tako tudi Ustavno sodišče v zadevi št. Up-140/02: "Sodišča morajo spoštovati odločitve Ustavnega sodišča v konkretni zadevi. če se ne strinjajo s stališči, izraženimi v njih, pa morajo prepričljivo utemeljiti, zakaj vprašanja, na katera opozarja obrazložitev, niso pomembna in jih sodišču ni treba razrešiti. Odločba sodišča, ki take predhodne odločbe ne upošteva in tudi prepričljivo ne argumentira, s katerimi stališči predhodne odločbe ne soglaša in zakaj, že iz tega razloga krši pravico do enakega varstva pravic iz 22. člena Ustave." V tej zadevi je šlo za sankcioniranje naknadnega neupoštevanja s strani Vrhovnega sodišča stališča Ustavnega sodišča, ki ga je to predhodno izrazilo v isti zadevi. 


\section{Marko Novak \\ Delna decentralizacija evropskega modela ustavnosodne presoje}

pritožb) pa bi s tem še vedno ohranili jezikovno-logični pomen besede "obvezno", bi bilo glede vezanosti (rednih) sodnikov na precedenčne odločitve Ustavnega sodišča $v$ t. i. Up-zadevah moč razlagati na takšna dva načina tudi drugi stavek 125. člena Ustave. ${ }^{39}$

Nepotrebna $v$ formalnem smislu pa bi bila tudi sprememba Ustave glede morebitne uvedbe diskrecijskega načina odločanja Ustavnega sodišča, saj bi to še naprej (če bi se tako odločili) lahko ohranilo vse dosedanje pristojnosti, ${ }^{\mathbf{4 0}}$ sam diskrecijski način pa bi bil bolj stvar zakonske materije (npr. v ZUstS), saj bi bilo treba urediti predvsem postopek izbiranja zadev (t. i. screening procedure), ki bi jih Ustavno sodišče sprejemalo v obravnavo.

Delnost decentralizacije bi bila $\vee$ tem, da sodišča (zaenkrat) ne bi razvijala svojega (ustavnosodnega) precedenčnega prava na različnih nivojih razsojanja (pravi decentralizacijski sistem), temveč bi samostojno odločala $\vee$ nekaterih ustavnosodnih zadevah na podlagi sodne prakse Ustavnega sodišča (delni decentralizacijski sistem), ki se je $v$ dosedanjih več kot desetih letih že dodobra strukturirala. Tu že omenjena Kelsnova skrb za enotnost ustavne razlage ne bi bila ogrožena oz. bi bila še dodatno ohranjena ter potrjena.

Redna sodišča bi tako morala obvezno ${ }^{\mathbf{4 1}}$ (tj. tudi formalno, $v$ smislu formalnega pravnega vira) - seveda le glede ustavnopravnih vprašanj - slediti precedensom Ustavnega sodišča (tj. odločbam Ustavnega sodišča, ki bi postale obvezni formalni pravni viri) v zadevah, ki se tičejo ustavne pritožbe oz. kršitev človekovih pravic. ${ }^{\mathbf{4 2}}$ Tako bi npr. višje (kazensko ali civilno) sodišče na podlagi precedensa Ustavnega sodišča razveljavilo sodbo okrožnega ali okrajnega sodišča, če bi ugotovilo kršitev človekovih pravic. Za enotno razlago tega dela ustavnega prava bi skrbelo Ustavno sodišče. ${ }^{\mathbf{4 3}}$

Ustavnopravno bi morda lahko takšen "prehod" v pravi precedenčni sistem veljave prejšnjih vzorčnih odločitev izvedli oz. utemeljili z ustrezno razlago 22.

39 "Vezani so na Ustavo in zakon."

40 Razen če bi se odločili npr. za spremembo Ustave iz podobnih razlogov kot v primeru morebitne uvedbe (delnega) precedenčnega sistema.

41 Seveda tudi ob ustrezni spremembi Zakona o sodiščih.

42 Kot je znano, se $v$ našem (evropsko-kontinentalnem) pravnem prostoru šteje, da sodne odločbe ne predstavljajo formalnega pravnega vira. $V$ tej zvezi glej npr. tudi stališča Vrhovnega sodišča RS: "V našem pravnem redu ne velja precedenčno pravo (po katerem predstavlja izrečena sodba formalni pravni vir za odločanje v enakih zadevah)." Sklep II Ips 498/94. "'Sodne odločbe niso pravni vir, zato sodna praksa sama po sebi ne more biti pravna podlaga za odločitev." Sodba VIII Ips 148/2003. Seveda poznamo namesto tega pri nas doktrino ustaljene sodne prakse, kjer pa gre lahko tudi za pomembne razlike $v$ primerjavi $s$ formalnim precedenčnim sistemom. 


\section{Marko Novak \\ Delna decentralizacija evropskega \\ modela ustavnosodne presoje}

Člena Ustave. Tako bi denimo menili, da že ena sama odločitev Ustavnega sodišča $\vee$ zadevah ustavnih pritožb pomeni ustaljenost sodne prakse, ${ }^{\mathbf{4 4}}$ ki jo morajo dosledno spoštovati nižja sodišča, tudi če Ustavno sodišče ni neposredno odločalo v "njihovi" zadevi.

Če pa redno sodišče ne bi imelo na voljo ustreznega precedensa Ustavnega sodišča oz. ko bi bila uporaba tega $v$ konkretnem primeru nejasna, bi to sodišče zahtevalo, da o tem zavzame stališče Ustavno sodišče. Tu bi šlo za postopek predhodnega odločanja, ki pa že zdaj obstaja $\vee$ okviru 156. člena Ustave $\vee$ primeru t. i. konkretne presoje ustavnosti. Sicer bi lahko redna sodišča uporabljala precedense Ustavnega sodišča $\vee$ konkretnih postopkih $\vee$ smislu doktrine acte claire Evropskega sodišča. ${ }^{\mathbf{4 5}}$ Če bi bilo Ustavno sodišče tudi na ta način bistveno razbremenjeno glede pripada zadev, bi tudi hitreje odločalo $v$ takšnih primerih.

Vendar je treba tu poudariti, da če bi sprejeli zgoraj omenjeno doktrino acte claire, potem popolna diskrecija Ustavnega sodišča ne bi bila mogoča, saj bi moralo obvezno odločati vsaj o vseh (utemeljeno postavljenih) "predhodnih" vprašanjih, ki bi jih postavila sodišča, drugače pravna varnost ne bi bila dovolj zagotovljena. Če pa bi vendarle skušali uvesti diskrecijsko odločanje Ustavnega sodišča, potem bi morali rednim sodiščem dopustiti, da sama odločajo $v$ primeru, ko $\vee$ določni zadevi ni prejšnje prakse Ustavnega sodišča oz. je uporaba njegovega precedensa nejasna. To bi namreč pomenilo, da bi tudi redna sodišča samostojno razvijala svojo sodno prakso glede ustavne razlage $v$ zvezi z varstvom človekovih pravic, Ustavno sodišče pa bi tu po možnosti reagiralo (v smislu enotenja oz. "zadnje besede" glede tovrstne ustavne razlage), če bi zadevo sprejelo v odločanje. Če pa takšne zadeve ne bi sprejelo $\checkmark$ odločanje po svoji diskrecijski pravici, pa bi se normalno štelo, da soglaša $s$ takšno ustavno razlago določene določbe o človekovi pravico oz. temeljni svoboščini.

43 Morda nekoliko podobno, kot to počne za evropsko pravo Evropsko sodišče $v$ Luksemburgu. Tudi tam je najpomembnejša enotna razlaga prava na nivoju celotnega ozemlja, za katerega velja (tj. EU).

44 Podobno, kot bi to veljalo za načelno mnenje Vrhovne sodišča $v$ "navadnih", tj. neustavnopravnih zadevah. Glej A. Galič, "Argument precedensa" ali Stališča Ustavnega sodišča RS o prepovedi samovoljnega odstopa od sodne prakse, Revus, let. 1, št. 1 (2003), str. 52.

45 Od Ustavnega sodišča npr. ne bi bilo treba zahtevati odločitve, če je o tem že odločilo oz. če je uporaba njegovih vzorčnih primerov tako jasna, da ne dopušča utemeljenega dvoma. Primerjaj z zadevo Cilfit (ECJ) z dne 6. oktobra 1982, Yearbook, str. 3415. 


\section{Marko Novak \\ Delna decentralizacija evropskega modela ustavnosodne presoje}

\subsection{Decentralizacija "abstraktne presoje"}

Če se zdi (vsaj delna) decentralizacija ustavne presoje smiselna $v$ primeru odločanja o kršitvah človekovih pravic in temeljnih svoboščin, pa to ne velja za t. i. abstraktno odločanje o pobudah in zahtevah glede domnevne neustavnosti oz. nezakonitosti ter glede drugih pristojnosti Ustavnega sodišča, ki jih ima po 160. členu Ustave. $V$ teh primerih bi tam, kjer je to smiselno, pristojnosti Ustavnega sodišča raje skrčili oz. odpravili. ${ }^{\mathbf{4 6}}$

Naj tu mimogrede opozorimo na Kelsnov argument za abstraktno presojo $\checkmark$ primerjavi $s$ povsem konkretizirano presojo $v$ decentraliziranem sistemu. Kelsen je namreč opozarjal, da glavni cilj določenega ameriškega postopka, kjer pride do takšne presoje, ni ugotovitev (ne)ustavnosti nekega zakona, temveč razrešitev konkretnega spora, takšno vprašanje pa se zastavlja le postransko. Nasprotno pa naj bi šlo $v$ kontinentalnem ustavnosodnem postopku (pri abstraktni presoji) za javni interes, ki nujno ne sovpada z interesom vpletenih strank. ${ }^{47}$ Če malce bolje poznamo Kelsnovo misel, bomo najbrž pomislili, da je tu najbrž ciljal na doseganje čim večje koherentnosti oz. popolnosti državnega pravnega sistema.

Sicer glede abstraktne presoje še vedno letijo kritike iz decentraliziranih sistemov ustavne presoje, češ da $v$ abstraktnem sistemu konkretnost (sodnost - t. i. justiciability) spora ni dovolj zagotovljena tedaj, ko se vprašanje ustavnosti pojavi $\vee$ konkretnih (sodnih ali upravnih) postopkih. Kljub temu še vedno menimo, da abstraktna ustavna presoja vendarle še vedno služi (vsaj) dvema pomembnima ciljema $\vee$ našem pravnem sistemu: (1) zaradi možnosti začasnega zadržanja domnevno neustavnega predpisa zagotavlja hitrejši in tudi obsežnejši dostop posameznika do ustreznega ustavnosodnega varstva kot pa $\checkmark$ primeru vložene ustavne pritožbe ${ }^{\mathbf{4 8}}$ ter (2) $\vee$ primeru vložene zahteve za presojo ustavnosti od t. i. kvalificiranih predlagateljev zagotavlja primerno stabilnost našega, delno še razvijajočega se pravno-političnega sistema, ko v odsotnosti večje vloge drugega zakonodajnega doma "pomirja" prevelika nasprotja med parlamentarno koalicijo in opozicijo.

46 O tem npr. glej (prihajajoče) spremembe Zakona o Ustavnem sodišču oz. Predlog Zakona o spremembah in dopolnitvah Zakona o Ustavnem sodišču (EVA: 2006-2011-0102), ki jih je pripravilo Ministrstvo za pravosodje (na spletni strani Ministrstva za pravosodje:http://www.mp.gov.si/fileadmin/mp.gov.si/pageuploads/2005/PDF/zakonodaja/2006_10_12_ predlog_ZUstS.pdf). Te nameravajo predvsem kratkoročno odpraviti enormni pripad zadev na Ustavno sodišče, dolgoročno pa se še vedno razmišlja o ustreznih spremembah Ustave. Glej J. Čebulj, Poročilo o delu za leto 2006, op. cit., str. 20-21.

47 H. Kelsen, Judicial Review of Legislation, op. cit., str. 193-194.

$48 \mathrm{O}$ tem glej več npr. J. Toplak, Ustavno sodišče - zakonodajalec, Pravna praksa št. 45 (2003), str. 3. 


\section{Marko Novak \\ Delna decentralizacija evropskega \\ modela ustavnosodne presoje}

Zakaj se $v$ teh tipih zadev delna decentralizacija ne bi zdela smiselna? Za to lahko naštejemo vsaj dva razloga:

(a) navadno gre za zelo zapletene analize ob skopem oz. izrazito abstraktnem besedilu ustavnih določb in za odločitve, ki imajo lahko daljnosežne politične posledice; ter

(b) o takšnih vprašanjih bo praviloma bolj kakovostno odločal tim izkušenih strokovnjakov skupaj s strokovno podporo svetovalcev kot pa sodnik posameznik (še posebej, če je neizkušen).

\section{Zaključna misel}

Od začetka delovanja evropskega tipa ustavnega sodišča, kot ga z delnimi popravki poznamo še danes, je minilo že skoraj sto let. Tako se glede na precej spremenjene okoliščine $v$ primerjavi $s$ tistimi, ki so obstajale takrat, ko je takšno sodišče pričelo delovati, $v$ zvezi z omenjenim problemom zdi, da bi nujno rabili še dodatne popravke.

Pri tem pa je najbolj pomembno, da bodo takšne morebitne spremembe prišle iz stroke zaradi strokovnih ugotovitev, ne pa da si bo takšne ali drugačne korekture (spet) uzurpirala politika zaradi doseganja njenih - zgolj kratkoročnih ciljev. Kelsnov centralizirani model ustavnosodne presoje se je $z$ določenimi spremembami namreč tako dolgo obdržal ravno zato, ker ga je izdelal vrhunski strokovnjak. Danes pa takšen model vendarle potrebuje še dodatne spremembe.

Marko Novak je diplomiral in doktoriral na Pravni fakulteti Univerze v Ljubljani, magistriral pa na Georgetown University Law School $v$ Washingtonu $v$ ZDA. Je pomočnik predstojnika Službe za analize in mednarodno sodelovanje na Ustavnem sodišču RS ter docent na Evropski pravni fakulteti v Novi Gorici ter Fakulteti za podiplomske državne in evropske študije, kjer predava predmeta Pravoznanstvo ter Filozofija in teorija prava. 


\section{Literatura in viri}

- Cornella, V. F. (2004), "The European model of constitutional review of legislation: Towards decentralization?", International Journal of Constitutional Law, str. 1-26

- Čebulj, J. (2005), Intervju, Delo 8. 11. 2005, str. 2

- Čebulj, J. (2007), Poročilo o delu (Ustavnega sodišča RS) za leto 2006, http://www.us-rs.si, str. 1-30

- Ferejohn, J. E. (2002), "Constitutional Review in the Global Context", Legislation and Public Policy, št. 6, str. 49-59

- Ferejohn, J. E. (2002), "Judicializing Politics, Politicizing Law", Law and Contemporary Problems, let. 65, št. 3, str. 41-68

- Galič, A. (2003), "Argument precedensa" ali Stališča Ustavnega sodišča RS o prepovedi samovoljnega odstopa od sodne prakse", Revus, let. 1, št. 1, str. 44-56

- Kelsen, H. (1942), "Judicial Review of Legislation, A Comparative Study of the Austrian and the American Constitution", The Journal of Politics, št. 4, str. 183-200

- Kelsen, H. (1934), "Reine Rechtslehre", Verlag Deuticke, Wien

- Lopez Guerra, L. (2005), "The Functions of Constitutional Courts", http://www.aals.org/profdev/constitutional/lopezguerra.html, str. 1-4

- Mavčič, A. (2001), "The Constitutional Review", Book World Publications, The Netherlands

- $\quad$ Novak, M. (2005), "Certiorari", Pravna praksa, št. 23, str. 21

- $\quad$ Roach Anleu, S. L. (2000), "Law and Social Change", SAGE Publications, London

- Stone, G. R. et al. (1991), "Constitutional Law", Little Brown and Company, Boston

- Toplak, J. (2003), "Ustavno sodišče - zakonodajalec", Pravna praksa, št. 45, str. 3

- Zweigert, K., Kotz, H. (1998), "Introduction to Comparative Law", Clarendon Press, Oxford 


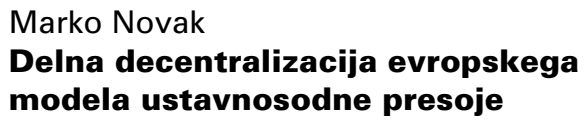

SUMMARY

\section{PARTIAL DECENTRALIZATION OF THE EUROPEAN MODEL OF CONSTITUTIONAL REVIEW}

Due to an increasingly unmanageable caseload of the Slovene Constitutional Court a proposal was made by certain lawyers to introduce a discretionary system of selecting cases for constitutional review (the socalled system of certiorari). In such event the Constitutional Court would, like the U. S. Supreme Court, also decide only on one or two hundred cases per year (instead of five thousands).

Such solution certainly appears to be a good response to the current problem, however, there are important differences between the legal systems in which the two mentioned Courts operate. On the one hand there is the Anglo-American legal family with the American model of constitutional review, on the other hand there is the European Continental legal family with the European model of constitutional review, both embracing distinct legal institutions and particularities. It is risky to simply take one institution and install it into another legal environment. Thus, in order to come close as much as possible to adopting the mentioned (American) discretionary system of selecting cases for constitutional review at least two conditions must be previously met.

The first condition would require the introduction of the so-called subsidiary system of constitutional review. This would entail that the constitutional court is on the top of the constitutional-review pyramid which presupposes that constitutional protection is also ensured at the level of lower courts. In the context, in which also lower courts would perform the review in certain cases. The European model of constitutional review would be partially decentralized.,

For this purpose, lower (ordinary) court would need to thoroughly follow (i.e. in the sense of respecting the formal effects of) the case law of the Constitutional Court - as they would represent the first level of such constitutional protection. In addition to that, by selecting a certain number of cases for review, the Constitutional Court would take care of the uniform interpretation of constitutional provision and of the development of such case law.

The second condition for the introduction of a discretionary system of selecting cases for constitutional review would be in that lower courts 
need to also formally adhere to previous "reference" cases of the Constitutional Court. In such a manner Constitutional Court decisions would become a formal source of law with the so-called "real" precedential (i.e. erga omnes) legal effects. This certainly does not entail that such decisions would be binding on lower court only in those cases of lower courts that came to the Constitutional Court (the so-called inter partes legal effect). According to the stare decisis doctrine, the formal validity of precedent entails that such effect is extended to all essentially similar cases, which means that all lower courts must apply such (in a similar manner as they apply law) if such cases are precedents decided, e.g., by a higher court within the same jurisdiction as the lower courts.

In such a manner precedents of the Constitutional Court would become (also formally) binding on all courts in the state - only, of course, concerning the interpretation of constitutional provisions. This would, however, leave lower courts still enough room in concrete cases to decide differently than the Constitutional Court when the two cases differ (different facts or different legal issues), which is common practice in common law legal systems. If two cases had essentially similar facts or legal issues, then the lower court would need to apply in that case the precedent of the higher court. The fact that already one decision of a higher court would be formally binding on all lower courts in the same jurisdiction would be much different than the existing doctrine of settled case law, adopted in European Continental legal systems, according to which there should be at least two or more essentially similar decisions in order for such case law to become settled in a certain area. The main problem with the latter is that it can produce much confusion because sometimes it is very hard to establish when such case law becomes settled.

Nevertheless, it seems that a partially decentralized system of constitutional review as described above would not be appropriate for exercising of all powers of the Constitutional Court. Therefore, it sounds reasonable to limit such only to human rights and fundamental freedom violations, which still represent the major part of the workload of our Constitutional Court. For the time being it seems that such a (partially decentralized) system would not be suitable for the so-called abstract constitutional review (i.e. the constitutional review of statutus and regulations), which generally requires a very complex and complicated analysis of which only top legal experts seem to be capable supported by a team of legal advisors rather than young inexperienced judges sitting on the 


\section{Marko Novak \\ Delna decentralizacija evropskega \\ modela ustavnosodne presoje}

bench alone. This is even so when we compare the situation in AngloAmerican legal systems, where constitutional review is also exercised by lower courts, which are, however, staffed by experienced judges who previously need to accomplish a successful career as an attorney or prosecutor.

Such a reform of the European model of constitutional review would certainly meet certain difficulties. One of them would be the fact that not only the Constitutional Court is loaded with cases but also lower (ordinary) courts, and giving them additional power would increase their caseload. Therefore, for this purpose their workload in other cases should be initially decreased and only then determined that they should assist the Constitutional Court on the lower level by deciding on (constitutional) human rights violations incidentally, i.e. together with other (e.g. statutory) legal issues if a concern of a (constitutional) human rights violation is made in such a case. 